\title{
PENERAPAN PIDANA TERHADAP PENYALAH GUNA NARKOTIKA UNTUK DIRINYA SENDIRI
}

\author{
Dahlan \\ Hakim Pengadilan Negeri Jakarta Utara \\ Dahlan9999@gmail.com
}

\begin{abstract}
Article 2 of Law Number 35 Year 2009 on Narcotics mentioned Narcotics Act based on Pancasila and the Constitution of the State of the Republic of Indonesia Year 1945. Subsequently Article 3 letter a mentioned Narcotics Act held based on keadilah. But in his enforcement does not describe the sense of justice. This research is normative juridical, that is method which describes or exposes a fact systematically then its analysis is conducted by juridical by linking between data and facts obtained by analyzing court decision related to criminal sanction to perpetrator of narcotic crime and related with regulation of law applicable. In order to achieve a common perception in the application of narcotic drug abuse for himself by law enforcement officials, it is necessary to reconstruct Law Number 35 Year 2009 on Article 132 Paragraph (1) to be: Experiment or conspiracy to commit narcotic crime and narcotics precursor as referred to in Article 111, Article 115, Article 119, Article 120, Article 121, Article 122, Article 123, Article 124, Article 125, Articles 126, 127, And Article 129, the perpetrator shall be subject to the same imprisonment in accordance with the provisions referred to in those Articles
\end{abstract}

Keywords : Criminal Implementation, Narcotics Abuse, Justice

\begin{abstract}
Abstrak
Pasal 2 Undang-Undang Nomor 35 Tahun 2009 tentang Narkotika disebutkan UndangUndang Narkotika berdasarkan Pancasila dan Undang-Undang Dasar Negara Republik Indonesia Tahun 1945. Selanjutnya Pasal 3 huruf a disebutkan Undang-Undang Narkotika diselenggarakan berasaskan keadilah. Namun dalam penegakannya tidak menggambarkan rasa keadilan. Penelitian ini bersifat yuridis normatif, yaitu metode yang menggambarkan atau memaparkan suatu fakta secara sistematis kemudian analisisnya dilakukan secara yuridis dengan mengaitkan antara data dan fakta yang diperoleh dengan menganalisa putusan pengadilan yang berkaitan dengan sanksi pidana terhadap pelaku tindak pidana narkotika dan dihubungkan dengan peraturan perundang-undangan yang berlaku. Untuk dapat terjadinya kesamaan persepsi dalam penerapan pidana penyalahguna narkotika untuk dirinya sendiri oleh aparat penegak hukum perlu direkonstruksi Undang-Undang Nomor 35 Tahun 2009 pada Pasal 132 ayat (1) menjadi: Percobaan atau permufakatan jahat untuk melakukan tindak pidana narkotika dan prekursor narkotika sebagaimana dimaksud dalam Pasal 111, Pasal 112, Pasal 113, Pasal 114, Pasal 115, Pasal 116, Pasal 117, Pasal 118, Pasal 119, Pasal 120, Pasal 121, Pasal 122, Pasal 123, Pasal 124, Pasal 125, Pasal 126, 127, dan Pasal 129, pelakunya dipidana dengan pidana penjara yang sama sesuai dengan ketentuan sebagaimana dimaksud dalam Pasal-Pasal tersebut.
\end{abstract}

Kata kunci : Penerapan Pidana, Penyalah Guna Narkotika, Keadilan

\section{A. PENDAhUlUAN}

Penegakan hukum merupakan salah satu cara menciptakan tata tertib, keamanan dan ketentraman, sebagai usaha pencegahan maupun pemberantasan atau penindakan setelah terjadinya pelanggaran hukum. ${ }^{1}$ Penegakan

Ratna Nurul Aflah, 2002, Barang Bukti Dalam Proses Pidana, Sinar Grafika, Jakarta, hlm.6. 
hukum adalah merupakan tugas negara ${ }^{2}$ yang salah satu perwujudannya dengan cara membentuk lembaga peradilan yang sekaligus diharapkan dapat melakukan koreksi dan rekoreksi terhadap hukum positif yang berlaku sesuai dengan perkembangan zaman yang diharapkan dapat mencerminkan nilai keadilan

Negara tidak boleh sewenang-wenang dalam menentukan perbuatan mana yang dianggap sebagai tindak pidana dan sanksi apa yang harus dijatuhkan pada si pelanggar, dan harus melandaskan pada prinsip persamaan dihadapan hukum sebagai cerminan keadilan, sebagaimana disebutkan dalam Pancasila sila ke 5 dan Pembukaan UUD NRI Tahun 1945 pada alinia ke 4. Mengenai prinsip persamaan hukum sebagai cerminan keadilan lebih ditegaskan lagi dalam pasal-pasal UUD NRI Tahun 1945 yakni:

Pasal 27 (1) menyebutkan: Segala warga negara bersamaan kedudukannya di dalam hukum dan pemerintahan dan wajib menjunjung hukum dan pemerintahan itu dengan tidak ada kecualinya.

Pasal 28 D (1) menyebutkan: Setiap orang berhak atas pengakuan, jaminan, perlindungan, dan kepastian hukum yang adli serta perlakuan yang sama di hadapan hukum.

Pasal $28 \mathrm{H}$ (2) menyebutkan: Setiap orang berhak mendapat kemudahan dan perlakuan khusus untuk memperoleh kesempatan dan manfaat yang sama guna mencapai persamaan dan keadilan.

Pasal 28 I (2) menyebutkan: Setiap orang bebas dari perlakuan yang bersifat diskriminatif

2 Disini negara, termasuk negara Indonesia, selaku penguasa dan dalam rangka melaksanakan penegakan hukum berhak menjatuhkan sanksi pidana dan merupakan satu-satunya subyek hukum yang mempunyai hak untuk menghukum (ius punindi). Alasan negara berhak untuk menjatuhkan sanksi pidana adalah tugas negara melindungi barang-barang hukum (rechsgoederen) secara menggunakan alat-alat yang sesuai (gepaste middelen), dan alat-alat yang sesuai itu secara sengaja mengancam atau menjatuhka penderitaan, dan penderitaa itu cukup keras memaksa yang bersangkutan bertindak layak dan menghindarkan yang bersangkutan melakukan perbuatan yang tidak layak. Lihat E. Utrecht, Rangkaian Sari Kuliah Hukum Pidana I, Pustaka Tintamas, Surabaya, 1987 , halaman 78 . atas dasar apapun dan berhak mendapatkan perlindungan terhadap perlakuan yang bersifat diskriminatif itu.

Pada saat ini pemerintah sedang gencar memerangi penyalahgunaan narkotika, Penyalahgunaan narkotika sudah bersifat transnasional (transnational criminality) karena dapat melintasi batas-batas negara (borderless countries) yang dilakukan dengan menggunakan modus operandi dan teknologi yang canggih, dengan jaringan manajemen yang rapi serta didukung pula oleh jaringan organisasi yang luas lalu masuk ke Indonesia sebagai negara transit (transit state) atau bahkan sebagai negara tujuan perdagangan narkotika secara illegal (point of market state) dan sudah banyak menimbulkan korban terutama di kalangan generasi muda bangsa hingga pada tingkat yang mengkhawatirkan sehingga sangat membahayakan sendi kehidupan masyarakat, bangsa dan negara, Pelaku penyalahgunaan narkotika pada dasarnya terbagi atas 2 (dua) katagori yaitu pelaku sebagai pengedar dan pelaku sebagai pemakai.

Penerapan sanksi pidana yang tersebar dalam pasal-pasal Undang-Undang Nomor 35 Tahun 2009 adalah merupakan bagian dari proses penegakan hukum yang dilakukan oleh penegak hukum dari mulai kepolisian/BNN selaku penyidik, kejaksaan selaku penuntut umum hingga diakhiri dengan adanya putusan hakim pada lembaga peradilan. Bentuk putusan yang akan dijatuhkan pengadilan bergantung pada hasil musyawarah hakim dengan mempertimbangkan fakta hukum pemeriksaan persidangan.

Pasal 2 Undang-Undang Nomor 35 Tahun 2009 berdasarkan Pancasila dan UUD NRI Tahun 1945, dan Pasal 3 menyebutkan: Undang-Undang Nomor 35 Tahun 2009 diselengarakan berasaskan keadilan, pengayoman, kemanusiaan, ketertiban, perlindungan dan keamanan. Dari rumusan tersebut pembentukan Undang-Undang Nomor 35 Tahun 2009 sesungguhmya berkeinginan mewujudkan nilai keadilan.

Dalam praktek peradilan kenyataannya penerapan pidana dalam Undang-Undang Nomor 35 Tahun 2009, khususnya Pasal 127 yakni penyalah guna narkotika untuk dirinya sendiri 
sebagai pemakai sangat bervariasi. Proses penegakan hukum mengenai UndangUndang Nomor 35 Tahun 2009 yang berimbas pada penerapan pidana adalah mengenai penentuan seorang pelaku untuk dapat dikualifikasikan sebagai penyalah guna narkotika untuk dirinya sendiri, antara sesama penegak hukum yakni penyidik, penuntut umum dan hakim karena tidak ada pedoman yang jelas untuk dapat dikatakan pelaku sebagai penyalah guna narkotika untuk dirinya sendiri, khususnya yang berkaitan dengan jumlah barang bukti dan menyangkut urine.

Berdasarkan kenyataan di persidangan, penyidik dan penuntut umum tetap berpedoman pada urine pelaku tanpa menghiraukan jumlah barang bukti yang hanya sekali pemakaian, jika urine pelaku negatif maka terhadap pelaku dikenakan/didakwakan dengan Pasal 111 untuk narkotika jenis tanaman atau Pasal 112 untuk narkotika bukan tanaman.

Pecandu adalah orang yang menggunakan atau menyalahgunakan narkotika dan dalam keadaan ketergantungan pada narkotika, baik secara fisik maupun psikis sedangkan penyalah guna adalah orang yang memakai narkotika yang tidak ada alasan hak atau melawan hukum. Namun dalam penegakannya sering terjadi penyalahgunaan kewenangan oleh aparat penegak hukum yaitu dengan menjerat pengguna narkoba dengan ketentuan yang jauh lebih berat, yaitu Pasal 111 atau Pasal 112 Undang-Undang 35 Tahun 2009 (memiliki, menyimpan, menguasai, menyediakan narkotika golongan I secara melawan hukum) yang diancam dengan ancaman hukuman penjara minimal 4 tahun, maksimal 12 tahun, dan denda minimal Rp 800 juta, maksimal Rp 8 milyar. Padahal seharusnya untuk pengguna (penyalah guna) narkotika lebih tepat diancam dengan Pasal 127 Undang-Undang Nomor 35 Tahun 2009 dimana golongan I ancaman maksimumnya hanya 4 tahun. Sedangkan untuk narkotika golongan II paling lama 2 (dua) tahun dan narkotika golongan III dengan pidana penjara paling lama 1 (satu) tahun tanpa adanya ancaman pidana denda.

Pasal 132 Undang-Undang Nomor 35 Tahun 2009 dalam hal percobaan ternyata tidak berlaku untuk Pasal 127, sehingga tidak dikenal istilah percobaan penyalah guna narkotika bagi diri sendiri. Hal tersebut berbeda dengan ketentuan dalam Kitab Undang-Undang Hukum Pidana (KUHP) yang mengenal istilah percobaan (vooging) untuk semua kejahatan sebagaimana dalam Pasal 53. Oleh karena dalam UndangUndang Nomor 35 Tahun 2009 tidak dikenal istilah percobaan bagi penyalah guna narkotika, maka dalam pemberkasan perkara oleh penyidik dan penuntut umum selalu berpedoman pada hasil pemeriksaan urine melalui laboratorium dan jika negatif maka kepada pelaku diberlakukan Pasal 111 atau Pasal 112 Undang-Undang Nomor 35 Tahun 2009 yang merupakan pasal karet atau pasal keranjang sampah.

Penerapan pidana yang berbeda sangat merugikan dan tidak menggambarkan rasa keadilan sebab seorang pengguna narkotika sebelum menggunakan narkotika dipastikan harus memiliki atau membeli terlebih dahulu, dan ketika narkotika telah dibeli atau dimiliki, sebelum dipergunakan telah ditangkap aparat kepolisian atau BNN sehingga otomatis hasil pemeriksaan laboratorium atas urine yang bersangkutan adalah negatif. Secara logika, terhadap pemakai narkotika dikenakan Pasal 127 dengan ancaman pidana maksimal 4 tahun bahkan dapat dikenakan pidana berupa tindakan rehabilitasi medis dan sosial, sangatlah tidak adil jika terhadap seseorang yang belum sempat memakai narkotika dikenakan Pasal 111 atau Pasal 112 yang ancaman pidananya minimal 4 (empat) tahun, maksimal 12 (dua belas) tahun ditambah denda minimal sejumlah Rp. $800.000 .000,-$ (delapan ratus juta rupiah).

Dalam hal ini, beberapa putusan pengadilan di Indonesia mengambil terobosan untuk mempertimbangkan pasal ini, meskipun dengan penerapan dibawah pidana minimum khusus ${ }^{3}$, atau tidak ada dalam dakwaan penuntut umum. ${ }^{4}$

3 Beberapa putusan pengadilan yang memutus di bawah pidana minumim khusus terhadap perkara narkotika, seperti: Putusan Nomor 2597/Pid.B/2009/ PN.Tng, atas nama terdakwa MN, Putusan Nomor 297/Pid.B/2010/PN.Tng, atas nama terdakwa JR, dan Putusan Nomor 904/Pid.B/2010/PN.Tng, atas nama terdakwa YW.

4 Beberapa putusan pengadilan yang memutus di luar dakwaan terhadap perkara narkotika, seperti: Putusan Nomor 337/Pid.Sus/2015/PN-Tjb, atas nama terdakwa Sulaeman als Leman, Putusan Nomor 338/Pid.Sus/2015/PN-Tjb, atas nama 
Menghadapi hal demikian, penulis tertarik meneliti karena bagi hakim tingkat pertama yang menjadi avant guard (garis depan) dalam menghadapi perkara di masyarakat kesamaan persepsi dan pandangan dari Mahkamah Agung terkait proses pemeriksaan di dalam prakteknya jika ditemukan fakta hukum yang berbeda dengan dakwaan penuntut umum khususnya perkara narkotika dapat menjadi suatu rujukan atau acuan dalam memutus suatu perkara yang diajukan kepadanya di kemudian hari meskipun disadari semua perkara adalah kasuistis sifatnya dan tidak ada perkara yang sama persis antara yang satu dengan yang lain. Dari fakta yang ada penulis menentukan perumusan masalah yang akan di bahas dalam jurnal ini yaitu:

1. Bagaimana konstruksi hukum terhadap penyalah guna narkotika untuk dirinya sendiri?

2. Bagaimana penerapan pidana terhadap penyalah guna narkotika untuk dirinya sendiri?

\section{B. Metode Penelitian}

Penulisan jurnal hukum ini berfokus mengkaji tentang rekonstruksi hukum dalam penerapan pidana penyalahguna narkotika untuk dirinya sendiri berbasis nilai keadilan.

Lebih lanjut dalam rangka mendapatkan informasi yang diperlukan dalam penelitian ini, sehingga dapat digunakan untuk menganalisis permasalahan hukum yang sedang dikaji, maka digunakan beberapa pendekatan yang lazim digunakan dalam penelitian hukum, yaitu pendekatan perundang-undangan (statute approach), pendekatan kasus (case approach), dan pendekatan konseptual (conceptual

terdakwa Saut Harianja, Putusan Nomor 339/Pid. Sus/2015/PN-Tjb, atas nama terdakwa Edi Saputra Rambe als Lumpang. Putusan Nomor 10/Pid.B/2012/ PN Msb atas nama terdakwa Muhammad Saleh als Saleh Bin Ogu, Putusan Nomor 55/Pid.B/2012/ PN.M atas nama terdakwa Ramli Bin Alm M Daali, Putusan Nomor 151/Pid.B/2011/PN.KTP atas nama terdakwa Widyawati alias Widya binti Jali, Putusan Nomor 1608/Pid.B/2012/PN.Sby atas nama terdakwa Idris Lukman bin Lokman Hendrik, Putusan Nomor 670K/Pid.Sus/2012 atas nama terdakwa Mansur bin Misnan dan Bagus Kurniawan bin Dharman Putusan Nomor 566K/Pid.Sus/2012 atas nama terdakwa Saifullah bin H Mursid. approach). ${ }^{5}$ Pendekatan-pendekatan tersebut digunakan untuk menjawab fokus penelitian.

Beberapa pendekatan yang digunakan dalam penelitian ini adalah: Pertama, pendekatan perundang-undangan (statute approach). Penelitian hukum dalam level dogmatik hukum atau penelitian untuk keperluan praktik hukum tidak dapat melepaskan diri dari pendekatan peraturan perundang-undangan. ${ }^{6}$ Dalam penelitian hukum ini, dikarenakan terkait dengan rekonstruksi hukum penerapan pidana penyalah guna narkotika untuk dirinya sendiri berbasis nilai keadilan, maka dirujuk berbagai peraturan yang terkait dengan kekuasaan kehakiman merupakan suatu pendekatan yang mutlak harus digunakan. Perspektif peraturan perundangundangan digunakan untuk menilai bagaimana rekonstruksi hukum penerapan pidana penyalah guna narkotika untuk dirinya sendiri berbasis nilai keadilan yang didesainkan saat ini sebagai titik fokus penelitian ini. Metode pendekatan yuridis normatif yang menguji dan mengkaji data sekunder yang berkaitan dengan permasalahan yang akan dibahas. Kemudan penulis akan mengkaji secara yuridis tentang penggunaan yurisprudensi atas putusan Mahkamah Agung yang dapat memutus di bawah ancaman minimal dan di luar dakwaan sepanjang pasal yang didakwakan tersebut adalah serumpun dan dikenakan ancaman di bawahnya dalam sistem peradilan pidana di Indonesia.

\section{Pembahasan}

\section{Konstruksi Hukum Terhadap Penyalah} Guna Narkotika Untuk Dirinya Sendiri

Pelaku tindak pidana narkotika memiliki peran, kedudukan, dan sanksi yang berbeda, baik berdasarkan peraturan perundangundangan yang mengaturnya maupun berdasarkan peran dan dampak yang ditimbulkan dari perbuatannya. Penggolongan pelaku tindak pidana narkotika dapat dilihat dari beberapa aspek sebagaimana dalam Undang-Undang Nomor 35 Tahun 2009 serta ketentuan perundang-undangan lainnya yang berkaitan dengan tindak pidana narkotika.

\footnotetext{
5 Peter Mahmud Marzuki, Penelitian Hukum, Kencana, Jakarta, hlm.93

6 Ibid, halaman 96
} 
Perbuatan penyalah guna narkotika bagi diri sendiri, diatur dalam Pasal 127, yaitu orang yang menggunakan narkotika tanpa hak atau melawan hukum (Pasal 1 angka 15). Sedangkan pecandu narkotika, sebagaimana dalam Pasal 128 dan Pasal 134 , yaitu orang yang menggunakan atau menyalahgunakan narkotika dan dalam keadaan ketergantungan pada narkotika, baik secara fisik maupun psikis (Pasal 1 angka 13).

Percobaan atau permufakatan jahat untuk melakukan tindak pidana narkotika dan prekursor narkotika dalam Pasal 111, Pasal 112, Pasal 113, Pasal 114, Pasal 115 , Pasal 116, Pasal 117, Pasal 118, Pasal 119, Pasal 120, Pasal 121, Pasal 122, Pasal 123 , Pasal 124, Pasal 125, Pasal 126, dan Pasal 129, sebagaimana diatur dalam Pasal 132.

Dalam Undang-Undang Nomor 35 Tahun 2009, terdapat 4 (empat) pengertian pengguna narkotika yaitu pecandu, penyalah guna, korban penyalahgunaan, dan pasien narkotika. Pecandu narkotika diartikan orang yang menggunakan narkotika dan dalam keadaan ketergantungan, baik secara fisik maupun psikis. Sedangkan penyalah guna adalah orang yang menggunakan narkotika tanpa hak atau melawan hukum. Korban penyalahgunaan narkotika diartikan seseorang yang tidak sengaja menggunakan narkotika karena dibujuk, diperdaya, ditipu, dipaksa, dan/atau diancam menggunakan narkotika. Terhadap pasien, tidak ditemukan pengertiannya. Merujuk kepada Pasal 53 Undang-Undang Nomor 35 Tahun 2009, dapat diartikan pasien adalah seseorang yang diberi hak memiliki, menyimpan, dan/ atau membawa narkotika dalam jumlah dan jenis terbatas sesuai dengan persetujuan dokter demi kepentingan pengobatan.

Selain Undang-Undang Nomor 35 Tahun 2009, terdapat juga Peraturan Pemerintah Nomor 25 Tahun 2011 tentang Pelaksanaan Wajib Lapor Pecandu Narkotika (Peraturan Pemerintah Nomor 25 Tahun 2011). Dimana dalam Pasal 13 (3) Peraturan Pemerintah Nomor 25 Tahun 2011 menyebutkan bahwa pecandu narkotika yang sedang menjalani proses peradilan dapat ditempatkan dalam lembaga rehabilitasi medis dan/atau rehabilitasi sosial. Selanjutnya disebutkan dalam ayat 4 bahwa penempatan dalam lembaga rehabilitasi medis dan/atau rehabilitasi sosial bagi pecandu narkotika yang sedang menjalani proses peradilan merupakan kewenangan penyidik, penuntut umum, atau hakim sesuai dengan tingkat pemeriksaan setelah mendapatkan rekomendasi dari tim dokter.

Dalam menangani pecandu narkoba, aparat penegak hukum harus berorientasi kepada sanksi tindakan berupa rehabilitasi demi menyelamatkan masa depan mereka. Untuk dapat memfungsikan peran hakim dalam memutus atau menetapkan rehabilitasi perlu dukungan dari aparat penegak hukum yang lain. Tentu hal ini harus berlandaskan pada adanya pemahaman dan kesepakatan bersama bahwa penyalahgunaan narkoba adalah masalah serius bangsa dan musuh bangsa. Pemahaman dan kesepakatan dari pemerintah dan aparat penegak hukum ini kemudian diwujudkan melalui Peraturan Bersama Ketua Mahkamah Agung, Menteri Hukum dan Hak Asasi Manusia, Menteri Kesehatan, Menteri Sosial, Jaksa Agung, Kepala Kepolisian, Kepala Badan Narkotika Nasional. Nomor 01/PB/MA/III/2014, Nomor 03 Tahun 2014, Nomor 11 Tahun 2014, Nomor 03 Tahun 2014, Nomor PER-005/A/JA/03/2014, Nomor 1 Tahun 2014, Nomor PERBER/01/ III/2014/BNN tentang Penanganan Pecandu Narkotika dan Korban Penyalahgunaan Narkotika ke dalam Lembaga Rehabilitasi. Dengan demikian pecandu narkoba tidak lagi bermuara pada sanksi pidana penjara melainkan bermuara di tempat rehabilitasi, karena sanksi bagi pecandu disepakati berupa rehabilitasi.

Hal ini sangat diperlukan dalam rangka mengoperasionalkan Pasal 54 Undang Undang Nomor 35 Tahun 2009 dimana pecandu narkotika wajib menjalani rehabilitasi medis dan rehabilitasi sosial. Dalam kaitan ini diharapkan penyalah guna narkoba akan dijerat dengan pasal penyalah guna saja (Pasal 127 Undang Undang Nomor 35 Tahun 
2009), dan selanjutnya hakim menggunakan Pasal 103 Undang-Undang Nomor 35 Tahun 2009 dimana hakim dapat memutus atau menetapkan untuk memerintahkan pecandu menjalani rehabilitasi.

Dalam penerapan pidana terhadap penyalah guna narkotika untuk dirinya sendiri, juga berpedoman kepada Surat Edaran Mahkamah Agung Nomor 04 Tahun 2010 tentang Penempatan Penyalah Guna, Korban Penyalahgunaan, dan Pecandu Narkotika ke dalam Lembaga Rehabilitasi Medis dan Rehabilitasi Sosial tentang Menempatkan Pemakai Narkotika ke Dalam Panti Terapi dan Rehabilitasi. Selain itu, Mahkamah Agung juga menerbitkan Surat Edaran Mahkamah Agung Nomor 03 Tahun 2011. Salah satu alasan dikeluarkannya SEMA tersebut adalah permasalahan tentang pecandu, korban penyalahgunaan narkotika yang semakin meningkat. Dikeluarkannya SEMA ini sebagai bentuk penegasan bahwa terhadap pecandu dan korban penyalahgunaan narkotika dapat dilakukan penempatan pada tempat tertentu yaitu dalam lembaga rehabilitasi medis dan rehabilitasi sosial. Penempatan yang sebenarnya sudah diakomodir dalam Penjelasan Pasal 21 (4) huruf b KUHAP, Pasal 54, 55, sampai dengan Pasal 59 UndangUndang Nomor 35 Tahun 2009, dan Pasal 13 dan 14 Peraturan Pemerintah Nomor 25 Tahun 2011

\section{Penerapan Pidana Terhadap Penyalah Guna Narkotika Untuk Dirinya Sendiri Berdasarkan penelitian terhadap beberapa kasus mengenai penerapan pidana terhadap penyalah guna narkotika untuk dirinya sendiri, yaitu:}

\section{Penerapan Pidana Penyalah Guna Narkotika Untuk Dirinya Sendiri Sesuai Dakwaan dan Penerapan Pidana Minimum Khusus}

\begin{tabular}{|c|c|c|c|}
\hline $\begin{array}{l}\text { Nomor Putusan / Nama } \\
\text { Terdakwa / Barang Bukti }\end{array}$ & Dakwaan & Tuntutan & Putusan \\
\hline $\begin{array}{l}\text { 90/PID.B/2015/PN.Tjb } \\
\text { Abdi Matondang als Abdi } \\
\text { Shabu 0,14 gram }\end{array}$ & $\begin{array}{l}\text { Pertama: Pasal } 114 \text { (1) } \\
\text { Undang-Undang Nomor } \\
35 \text { Tahun } 2009 . \\
\text { Kedua: Pasal } 112 \text { (1) } \\
\text { Undang-Undang Nomor } \\
35 \text { Tahun } 2009\end{array}$ & $\begin{array}{l}\text { Pasal } 112(1) \text { Undang- } \\
\text { Undang Nomor } 35 \\
\text { Tahun } 2009 \\
\text { Pidana penjara selama } \\
9 \text { tahun dan denda Rp. } \\
800.000 .000 \text { subsidair } \\
6 \text { bulan penjara }\end{array}$ & $\begin{array}{l}\text { Pasal } 112 \text { (1) } \\
\text { Undang-Undang } \\
\text { Nomor } 35 \text { Tahun } \\
2009 \\
\text { Pidana penjara } \\
\text { selama } 6 \text { tahun } \\
\text { dan denda Rp. } \\
800.000 .000 \\
\text { subsidair } 6 \text { bulan } \\
\text { penjara }\end{array}$ \\
\hline $\begin{array}{l}\text { 114/PID.B/2015/PN.Tjb } \\
\text { Nurmala } \\
\text { Shabu } 0,20 \text { gram }\end{array}$ & $\begin{array}{l}\text { Pertama: Pasal } 114 \\
\text { (1) jo Pasal } 132 \text { (1) } \\
\text { Undang-Undang Nomor } \\
35 \text { Tahun } 2009 . \\
\\
\text { Kedua: Pasal } 112(1) \text { jo } \\
\text { Pasal } 132(1) \text { Undang- } \\
\text { Undang Nomor } 35 \\
\text { Tahun } 2009 . \\
\text { Ketiga: Pasal } 131 \\
\text { Undang-Undang Nomor } \\
\text { 35 Tahun } 2009 .\end{array}$ & $\begin{array}{l}\text { Pasal } 112(1) \text { jo Pasal } \\
132(1) \text { Undang- } \\
\text { Undang Nomor } 35 \\
\text { Tahun } 2009 . \\
\text { Pidana penjara selama } \\
6 \text { tahun dan denda Rp. } \\
800.000 .000 \text { subsidair } \\
6 \text { bulan penjara }\end{array}$ & $\begin{array}{l}\text { Pasal } 112(1) \text { jo } \\
\text { Pasal } 132(1) \\
\text { Undang-Undang } \\
\text { Nomor } 35 \text { Tahun } \\
2009 \\
\\
\text { Pidana penjara } \\
\text { selama } 5 \text { tahun } \\
\text { dan denda Rp. } \\
800.000 .000 \text {, } \\
\text { subsidair } 4 \text { bulan } \\
\text { penjara }\end{array}$ \\
\hline
\end{tabular}




\begin{tabular}{|c|c|c|c|}
\hline $\begin{array}{l}\text { Nomor Putusan / Nama } \\
\text { Terdakwa / Barang Bukti }\end{array}$ & Dakwaan & Tuntutan & Putusan \\
\hline $\begin{array}{l}\text { 185/PID.B/2015/PN.Tjb } \\
\text { Syahputra Budidaya als } \\
\text { Budi } \\
\text { Shabu } 0,28 \text { gram }\end{array}$ & $\begin{array}{l}\text { Pertama: Pasal } 114(1) \\
\text { Undang-Undang Nomor } \\
35 \text { Tahun } 2009 . \\
\text { Kedua: Pasal } 112 \text { (1) } \\
\text { Undang-Undang Nomor } \\
35 \text { Tahun } 2009\end{array}$ & $\begin{array}{l}\text { Pasal } 112(1) \text { Undang- } \\
\text { Undang Nomor } 35 \\
\text { Tahun } 2009 . \\
\text { Pidana penjara selama } \\
4 \text { tahun dan denda Rp. } \\
800.000 .000 \text { subsidair } \\
6 \text { bulan penjara }\end{array}$ & $\begin{array}{l}\text { Pasal } 112 \text { (1) } \\
\text { Undang-Undang } \\
\text { Nomor } 35 \text { Tahun } \\
\text { 2009: } \\
\text { Pidana penjara } \\
\text { selama } 7 \text { tahun } \\
\text { dan denda Rp. } \\
800.000 .000 \\
\text { subsidair } 6 \text { bulan } \\
\text { penjara }\end{array}$ \\
\hline $\begin{array}{l}\text { 421/PID.B/2015/PN.Tjb } \\
\text { Kaharuddin als Den } \\
\text { Shabu 0,17 gram }\end{array}$ & $\begin{array}{l}\text { Primair: Pasal } 114(1) \\
\text { Undang-Undang Nomor } \\
35 \text { Tahun } 2009 . \\
\\
\text { Subsidair: Pasal } 112(1) \\
\text { Undang-Undang Nomor } \\
35 \text { Tahun } 200\end{array}$ & $\begin{array}{l}\text { Pasal } 112(1) \text { Undang- } \\
\text { Undang Nomor } 35 \\
\text { Tahun } 2009 \\
\text { Pidana penjara } 5 \\
\text { tahun dan denda Rp. } \\
800.000 .000 \text { subsidair } \\
6 \text { bulan penjara }\end{array}$ & $\begin{array}{l}\text { Pasal } 112(1) \\
\text { Undang-Undang } \\
\text { Nomor } 35 \text { Tahun } \\
2009 . \\
\text { Pidana penjara } 4 \\
\text { tahun dan denda } \\
\text { Rp. } 800.000 .000 \\
\text { subsidair } 6 \text { bulan } \\
\text { penjara }\end{array}$ \\
\hline
\end{tabular}

\section{Penerapan Pidana Penyalah Guna Narkotika Untuk Dirinya Sendiri Sesuai Dakwaan dan Penerapan Pidana Dibawah Minimum Khusus}

\begin{tabular}{|l|l|l|l|}
\hline $\begin{array}{l}\text { Nomor Putusan / Nama } \\
\text { Terdakwa / Barang Bukti }\end{array}$ & \multicolumn{1}{|c|}{ Dakwaan } & \multicolumn{1}{|c|}{ Tuntutan } & \multicolumn{1}{|c|}{ Putusan } \\
\hline $\begin{array}{l}\text { 2597/Pid.B/2009/PN.Tng } \\
\text { MN 16 Tahun } \\
\text { Ganja 0,3810 gram }\end{array}$ & $\begin{array}{l}\text { Pasal 111 (1) Undang- } \\
\text { Undang Nomor 35 } \\
\text { Tahun 2009 }\end{array}$ & $\begin{array}{l}\text { Pasal 111 (1) Undang- } \\
\text { Undang Nomor 35 } \\
\text { Tahun 2009 }\end{array}$ & $\begin{array}{l}\text { Pasal 111 (1) } \\
\text { Undang-Undang } \\
\text { Nomor 35 Tahun } \\
2009\end{array}$ \\
& & $\begin{array}{l}\text { Pidana penjara 4 } \\
\text { tahun dan denda Rp. } \\
800.000 .000 \text { subsidair 1 1 } \\
\text { bulan latihan kerja }\end{array}$ & $\begin{array}{l}\text { Pidana penjara 2 } \\
\text { tahun dan denda } \\
\text { Rp. 400.000.000 } \\
\text { subsidair 1 bulan } \\
\text { latihan kerja }\end{array}$ \\
\hline $\begin{array}{l}\text { 297/Pid.B/2010/PN. Tng } \\
\text { JR 16 Tahun } \\
\text { ganja 4,0489 gram }\end{array}$ & $\begin{array}{l}\text { Pasal 111 (1) Undang- } \\
\text { Undang Nomor 35 } \\
\text { Tahun 2009 }\end{array}$ & $\begin{array}{l}\text { Pasal 111 (1) Undang- } \\
\text { Undang Nomor 35 } \\
\text { Tahun 2009 }\end{array}$ & $\begin{array}{l}\text { Pasal 111 (1) } \\
\text { Undang-Undang } \\
\text { Nomor 35 Tahun } \\
\text { 2009 }\end{array}$ \\
& & $\begin{array}{l}\text { Pidana penjara 4 } \\
\text { tahun dan denda Rp. } \\
\text { 800.000.000 subsidair 3 3 } \\
\text { bulan penjara }\end{array}$ & $\begin{array}{l}\text { Pidana penjara 2 } \\
\text { Tahun dan denda } \\
\text { Rp. 400.000.000 } \\
\text { subsidair. 1 bulan } \\
\text { latihan kerja }\end{array}$ \\
\hline
\end{tabular}




\begin{tabular}{|l|l|l|l|}
\hline $\begin{array}{l}\text { Nomor Putusan / Nama } \\
\text { Terdakwa / Barang Bukti }\end{array}$ & \multicolumn{1}{|c|}{ Dakwaan } & \multicolumn{1}{|c|}{ Tuntutan } & \multicolumn{1}{|c|}{ Putusan } \\
\hline $\begin{array}{l}\text { 904/Pid.B/2010/PN. Tng } \\
\text { YW 15 Tahun } \\
\text { ganja 0,8744 gram }\end{array}$ & $\begin{array}{l}\text { Pasal 111 (1) jo 132 } \\
\text { (1) Undang-Undang } \\
\text { Nomor 35 Tahun 2009 }\end{array}$ & $\begin{array}{l}\text { Pasal 111 (1) jo 132 (1) } \\
\text { Undang-Undang Nomor } \\
\text { 35 Tahun 2009 }\end{array}$ & $\begin{array}{l}\text { Pasal 111 (1) jo } \\
132(1) \text { Undang- } \\
\text { Undang Nomor 35 } \\
\text { Tahun 2009 }\end{array}$ \\
& & $\begin{array}{l}\text { Pidana penjara 4 } \\
\text { tahun dan denda Rp. } \\
\text { 800.000.000 subsidair 6 } \\
\text { bulan penjara }\end{array}$ & $\begin{array}{l}\text { Pidana penjara 3 } \\
\text { tahun dan denda } \\
\text { Rp. 800.000.000,- } \\
\text { subsidair. 2 bulan } \\
\text { penjara }\end{array}$ \\
\hline
\end{tabular}

Adanya dua kecenderungan pola pikir hakim dalam menangani perkara penyalah guna narkotika untuk dirinya sendiri, yaitu pola pikir hakim positivistik dan pola pikir hakim non positivistik. Pola pikir hakim corak yang pertama menekankan pada ukuran formal teks aturan dalam menggali kebenaran hukum, pola pikir kedua mengelaborasikan teks aturan hukum dengan konteks sosiolegal dalam menggali kebenaran hukum.

Pentingnya konstruksi baru pola pikir hakim bertolak dari kondisi existing (hasil studi) atas penanganan perkara (penyalah guna narkotika untuk dirinya sendiri) oleh hakim di pengadilan saat ini banyak mengalami kemerosotan atau kegagalan untuk menghadirkan hukum yang adil, bermanfaat dan melindungi kepentingan masyarakat (social justice). Pola pikir hakim yang bercorak positivistik perlu dibangun kembali (ditata ulang) berdasarkan pola pikir baru yang progresif dalam menyelesaikan problem hukum yang muncul akhir-akhir ini yang semakin kompleks dan rumit, terutama dalam memecahkan masalah penyalah guna narkotika untuk dirinya sendiri.

Kenyataan atau keadaan dimana keputusan harus diambil dengan amat memperhitungkan konteks yang ada. Begitu kompleknya kenyataan sehingga hampir mustahil memperoleh keputusan yang adil hanya dengan mengandalkan pertimbangan legalistik semata. Oleh karena itu, kehadiran pelaku hukum yang arif dan kreatif, mutlak perlu untuk memandu penafsiran yang luas dan kreatif terhadap aturan-aturan yang demikian itu. Seorang pelaku hukum progresif berusaha mencari dan menemukan keadilan dalam batas dan di tengah keterbatasan kaidah-kaidah hukum yang ada.

\section{PENUTUP}

\section{Kesimpulan}

1. Terhadap pelaku tindak pidana penyalah guna narkotika bagi diri sendiri, Undang-Undang Nomor 35 Tahun 2009 telah mengaturnya dalam Pasal 127 (1), (2) dan (3), penerapan pidana hakim mengacu kepada SEMA Nomor 4 Tahun 2010, serta peraturan bersama tentang Penanganan Pecandu Narkotika dan Korban Penyalahgunaan Narkotika ke dalam Lembaga Rehabilitasi.

2. Penyalah guna narkotika untuk dirinya sendiri seharusnya diterapkan ketentuan Pasal 127 UndangUndang Nomor 35 Tahun 2009, dan dilakukan rehabilitasi, namun dengan penerapan Pasal 111, 112, dan 114 Undang-Undang Nomor 35 Tahun 2009, menyebabkan penyalah guna narkotika untuk dirinya sendiri harus menjalani pidana Sehubungan penyalah guna narkotika untuk dirinya sendiri yang tertangkap sebelum melakukan penyalahgunaan narkotika, dapat diterapkan ketentuan percobaan penyalahgunaan narkotika. Untuk dapat terjadinya kesamaan persepsi dalam penerapan pidana penyalah guna narkotika untuk dirinya 
sendiri oleh aparat penegak hukum perlu direkonstruksi Undang-Undang Nomor 35 Tahun 2009 pada Pasal 132 (1) menjadi: Percobaan atau permufakatan jahat untuk melakukan tindak pidana narkotika dan prekursor narkotika sebagaimana dimaksud dalam Pasal 111, Pasal 112, Pasal 113, Pasal 114, Pasal 115, Pasal 116, Pasal 117, Pasal 118, Pasal 119, Pasal 120, Pasal 121, Pasal 122, Pasal 123, Pasal 124, Pasal 125, Pasal 126, 127, dan Pasal 129, pelakunya dipidana dengan pidana penjara yang sama sesuai dengan ketentuan sebagaimana dimaksud dalam pasal-pasal tersebut.

\section{Saran}

1. Munculnya undang-undang, termasuk Undang-Undang Nomor 35 Tahun 2009 , sebenarnya hasil dari suatu kompromi politik, oleh karena rumusan undang-undang itu sendiri dapat dikatakan bukan merupakan kebenaran mutlak. Justru karena rumusannya tersebut bukan kebenaran mutlak, maka di dalamnya pastinya mengandung kekeliruan manusia dan lagi pula rumusan peraturan undang-undang tersebut tidak dapat menunjang maupun mencakup kepentingan manusia yang luas

2. Hendaknya di dalam setiap menjatuhkan putusan dalam perkara tindak pidana narkotika, hakim senantiasa harus berusaha memasukkan ketiga unsur, yang meliputi keadilan (gerechtigkeit), kepastian hukum (rechtsicherheit) dan kemanfaatan (zwechtmassigkeit), di dalam setiap putusannya, dan bukan sebaliknya hanya berusaha memprioritaskan atau mengutamakan satu unsur saja lalu mengabaikan unsur yang lainnya, sehingga nantinya putusan yang dihasilkannya tersebut bisa berkualitas dan sesuai dengan yang diharapkan oleh para pencari keadilan (justiciabellen) yakni putusan yang mengandung legal justice, moral justice, dan social justice

\section{DAFTAR PUSTAKA}

\section{- Buku-buku}

Muladi dan Barda Nawawi Arief, 1992, Teori dan Kebijakan Pidana, Alumni, Bandung,;

Peter Mahmud Marzuki, 2009, Penelitian Hukum, Kencana, Jakarta;

Ratna Nurul Aflah, 2002, Barang Bukti Dalam Proses Pidana, Sinar Grafika, Jakarta

Mumtaz Ahmad, 1994, Masalah-Masalah Teori Politik Islam, Mizan, Bandung;

R Soesilo, 1980, Kitab Undang-Undang Hukum Pidana (KUHP) serta Komentar-Komentarnya Lengkap Pasal Demi Pasal, Politea, Bogor, 1980.

Salim H S dan Erlies Septiana Nurbani, 2013, Penerapan Teori Hukum Pada Penelitian Tesis dan Disertasi, Raja Grafindo Persada, Jakarta;

Samidjo,1985, Pengantar Hukum Indonesia, Armico, Bandung, 1985

S. R. Sianturi, 1996, Asas-asas Hukum Pidana di Indonesia dan Penerapannya. Peteheam, Jakarta;

Satjipto Rahardjo, 2007, Biarkan Hukum Mengalir (Catatan Kritis Tentang Pergulatan Manusia dan Hukum), Penerbit Buku Kompas, Jakarta, 2007 